\title{
Variation in the response of intertidal infaunal invertebrates to nutrient additions: field manipulations at two sites within Port Phillip Bay, Australia
}

\author{
Liz Morris ${ }^{1,2, *}$, Michael J. Keough ${ }^{2}$ \\ ${ }^{1}$ Department of Zoology, University of Melbourne, Melbourne 3010, Australia \\ ${ }^{2}$ Present address: Marine and Freshwater Resources Institute, PO Box 114, Queenscliff 3225, Australia
}

\begin{abstract}
Nutrient addition experiments are one way of testing the importance of nutrients in ecological systems and can be undertaken relatively easily in soft sediments. We added nutrients (Osmocote $^{\circledR}$ ) at 2 sites in Port Phillip Bay, Australia, which differed in proximity to sources of nutrient loading. Changes in faunal assemblages were assessed over an $18 \mathrm{wk}$ experimental period in 1998. At the Sand Island site, nitrate levels were elevated in the high dose treatments and 3 taxa showed responses to nutrient additions, with differences in densities between control and dosed plots of between 50 and $600 \%$. Assemblage-level measures of total abundance and diversity were approximately 20 to $80 \%$ greater in dosed plots relative to controls at the end of the experimental period. In contrast, at the more enriched Western Treatment Plant site, 3 of the 10 most dominant taxa were affected by the nutrient additions, with changes of between 50 and $200 \%$ observed during the course of the experiment. At this site none of the assemblage level measures of abundance, biomass and diversity reflected an effect of the dose treatments. These results are broadly consistent with other studies that suggest that in areas of low ambient nutrient availability diversity is likely to increase, while in areas with high background nutrient loadings there is likely to be a decrease. At Sand Island, changing the nutrient status of the area is liable to result in rapid changes in several deposit-feeding populations. At the Western Treatment Plant, the same absolute change in $\mathrm{N}$ may have less impact on the invertebrate fauna.
\end{abstract}

KEY WORDS: Western Treatment Plant $\cdot$ Swan Bay $\cdot$ Victoria $\cdot$ Benthos $\cdot$ Macroinvertebrates $\cdot$ Field experiments $\cdot$ Experimental power

\section{INTRODUCTION}

Nutrient addition or fertilisation experiments are one way of testing the importance of nutrients in ecological systems (Cecchererelli \& Cinelli 1997), and they have been successfully used in freshwater environments at a range of scales, including whole lake (e.g. Houser et al. 2000) and smaller scale manipulative experiments (Biggs \& Lowe 1994, Biggs et al. 2000). In marine systems nutrient addition experiments have also been used to examine the effect of nutrient loading on bacteria (Sundback et al. 1990), microalgal growth and production (Breitburg et al. 1999, Downing et al. 1999), meiofauna (Nilsson et al. 1991, Schratzberger \& Warwick 1998), seagrass growth parameters (Bulthius et al. 1992, Kenworthy \& Fonesca 1992, McGlathery 1995), temperate rocky reef assemblages (Hall et al. 2000) and coral reef assemblages (e.g. Fleury et al. 2000). Surprisingly, given the prevalence of soft sediment macrofaunal monitoring studies, there are very few examples of experimental fertilisation of intact assemblages of soft sediment macrofauna (but see Dauer et al. 1982, Wiltse et al. 1984, Posey et al. 1995, 1999, Vetter 1996).

The addition of nutrients to sediments is predicted to increase the growth of benthic microalgae and bacterial assemblages which, in turn, is predicted to increase the 
abundance and biomass of grazing populations - the classical 'bottom-up' model of assemblages regulated by nutrient supply (McQueen et al. 1989). It is only recently that marine research has contributed to the ongoing ecological debate about bottom-up and top-down regulation of assemblages. This has been partly attributed to the open nature of marine systems and the associated logistical difficulties of undertaking enrichment experiments (Menge 1992). Soft sediments actually provide an ideal environment to undertake fertilisation experiments because controlled-release fertilisers can be buried in the sediment so that readily available inorganic nutrients can be applied at different dose rates (e.g. Kenworthy \& Fonesca 1992, Erftemeijer et al. 1994). This form of application focuses particularly on the effects of increasing available inorganic nutrients and thereby stimulating benthic microalgal production.

The response of benthic assemblages receiving nutrient additions may vary considerably depending on prevailing environmental conditions. If nutrients are not limiting, then there may be no increase in microalgal biomass and therefore no concomitant increase in abundance and biomass of grazing populations (Posey et al. 1999). A range of other biotic and abiotic factors may also be important in determining the effects of fertilisation on intermediate trophic levels (Hunter \& Price 1992), including turbidity, physical disturbance (Cahoon et al. 1999) and the intensity of biotic interactions such as predation and competition (Reibsell 1974, Pearson \& Rosenberg 1987). As a consequence, predictions regarding the responses of infaunal assemblages to nutrient additions vary. While grazing and deposit-feeding populations are predicted to show the most marked responses to nutrient additions, univariate measures of assemblage structure (diversity etc.) may respond differently between sites that differ in nutrient loading (Wiltse et al. 1984, Schratzberger \& Warwick 1998).

The addition of nutrients and the associated predicted increase in algal biomass might also affect the chemical nature of the sediment, as the anaerobic decomposition of excess organic material by certain bacteria will result in the formation of hydrogen sulphide (Fenchel \& Reidl 1970) or hypoxic conditions. As the deeper sediments become increasingly deoxygenated, a wide variety of organisms have been shown to migrate through the sediment (e.g. Llanso 1991, Rosenberg et al. 1991, Taylor \& Eggleston 2000), and therefore we predicted that the addition of nutrients to experimental plots would result in a net movement of organisms towards the sediment surface.

The main objectives of this study were to test whether infaunal assemblages would show responses to nutrient additions at 2 different sites within Port Phillip Bay, Victoria, Australia.

\section{MATERIALS AND METHODS}

Study sites. Western Treatment Plant: The Western Treatment Plant (WTP) is a major sewage processing plant that covers 10851 ha, including approximately $20 \mathrm{~km}$ of foreshore over which 4 main drains discharge secondary treated effluent into Port Phillip Bay, Victoria, Australia. Two rivers (Werribee River and Little River) also discharge into the bay, immediately adjacent to, and within the WTP, respectively. The WTP is the source of the single largest input of $\mathrm{N}$ to the bay (Heggie et al. 1999). This area is also one of the most important areas for wading and shore birds in Victoria (Steele 1996) and is part of a larger area designated a wetland of international importance (Ramsar site). The experimental site was situated on an intertidal mudflat approximately $2 \mathrm{~km}$ southwest of the Lake Borrie Drain that discharges approximately 50 million 1 of effluent per day. Large dumps of drift algae occur periodically in the intertidal region and the weed can remain onshore for a period of days to weeks. The drift alga is potentially another major source of nutrients in the intertidal region, although there were no major weed dumps during the duration of the experiments reported here.

Sand Island: Sand Island is situated in the larger area of Swan Bay also within Port Phillip Bay, Victoria, Australia. It has been formed over the last $30 \mathrm{yr}$ by the deposition of dredged material and natural sand accretion. As with the WTP, Sand Island is situated within a Ramsar site. We carried out the experiment on an intertidal flat consisting of muddy sand with organic debris incorporated into the top $2 \mathrm{~cm}$ of the sediment. In Swan Bay as a whole, a pattern of algal growth and seagrass decline consistent with an introduction of excess nutrients has been observed (Ball \& O'Callaghan 1997) but this area supports lower infaunal and shorebird densities than the Western Treatment Plant foreshore.

Field manipulation. Following a review of in situ nutrient enrichment experiments, Worm et al. (2000) recommended the use of coated slow-release fertilisers for sediment and water column enrichment experiments. We added nutrients to the sediment in the form of a controlled release fertiliser, Osmocote ${ }^{\circledast}$ for outdoors, which has a N:P ratio of 18:4.8 and a release rate of 6 to 9 mo. This particular formulation of Osmocote ${ }^{\circledR}$ was chosen as its $\mathrm{N}: \mathrm{P}$ ratio most closely resembled that of the Lake Borrie Drain. The use of this type of coated fertiliser allows for good, long-term enrichment rates and has been shown to provide a steady release of nutrients (Worm et al. 2000). Fertiliser was applied at 3 dose rates of 25,100 and $500 \mathrm{~g}$ to small randomly assigned plots $\left(0.16 \mathrm{~m}^{2}\right)$ that were at least $3 \mathrm{~m}$ apart, in the mid-shore level of the intertidal, via perforated plastic pots buried 
just below the sediment surface. Controls consisted of empty plastic pots buried in exactly the same way. This level of dosing is consistent with other studies that have used similar methodologies to enrich sediments and have recorded biological responses to the experimental manipulation (see Worm et al. 2000 for review). We decided to use a point source approach because adding the fertiliser granules directly to the sediment would change the effective grain size of the sediment, which may be very important in structuring benthic assemblages (but see Snelgrove \& Butman 1994). Plots were marked with stakes and triangulation methods were used to find the position of the buried pots on subsequent sampling occasions.

Samples were taken at $6 \mathrm{wk}$ intervals after deployment of the fertiliser and the experiments ran for $18 \mathrm{wk}$, from the end of February to the end of June 1998. There were 4 replicate plots of each treatment, and the position of the plots on the shore and assignation of the dose treatments to plots were completely randomised. Faunal samples were taken $15 \mathrm{~cm}$ from the centre of the dosing pot, which meant that the edge of the corer was $10 \mathrm{~cm}$ away from the edge of the dosing pot. Faunal samples were taken with a $9 \mathrm{~cm}$ internal diameter corer to a depth of $10 \mathrm{~cm}$. Each sample was split into depth fractions of $0-2,2-4,4-6$, and $8-10 \mathrm{~cm}$ depths. Due to problems with sample storage, there is not a complete data set for each site as some samples had degraded to the extent that soft-bodied organisms were not identifiable. Consequently we are restricted to presenting the 0,6 and 18 wk sampling occasions for the WTP site and the 0,12 and $18 \mathrm{wk}$ sampling occasions for the Sand Island site, with at least 3 replicates per treatment in all cases. At the Sand Island site we were able to census hard-bodied organisms in samples where soft-bodied animals were lost; consequently, sample number differs between different groups.

Samples for chl a analysis were taken from the same distance as the faunal samples using a $20 \mathrm{ml}$ cut-off syringe and they were divided into four and five $2 \mathrm{~cm}$ depth strata at the WTP and Sand Island respectively. Sediment at the WTP site overlies a shell base, which made it difficult to sample to $10 \mathrm{~cm}$ with the syringe, and therefore only 4 depth strata were sampled at this site. Sediment samples were also taken for organic carbon analysis. In this case one sample was taken that integrated sediment from the entire $10 \mathrm{~cm}$ depth of the faunal samples.

The objectives of this study relate to the invertebrate fauna, and as a consequence the infaunal measures, chl $a$ concentrations and organic carbon measures have the most immediate biological relevance. The Osmocote ${ }^{\circledR}$ preparation of $\mathrm{N}$ consisted of a mixture of nitrates and ammonium, and, while the most appropriate nutrient to measure will be very dependent on site, we chose porewater nitrate concentrations as a chemical marker for the dose application. In Port Phillip Bay it is thought likely that $\mathrm{N}$ is the limiting nutrient as levels of $\mathrm{P}$ measured in both the sediment and water column were consistently high (Harris et al. 1996). Samples for nitrate analysis were taken at 3 distances from the dosing pots, 10,20 and $50 \mathrm{~cm}$, because we wanted to test for a gradient effect of the dose addition with distance from the buried pot. All the samples taken for sediment chemistry analysis were stored in a cool box and frozen $\left(-80^{\circ} \mathrm{C}\right)$ immediately on return to the laboratory.

Laboratory techniques. Organisms in the sediment cores were sieved through a $0.5 \mathrm{~mm}$ sieve and the residue counted and identified to the lowest practicable level under a binocular microscope. Wet weight biomass of each species group was also recorded to the nearest $0.001 \mathrm{~g}$.

Chl a was extracted using the hot methanol technique (Hill \& Hawkins 1990). The $7 \mathrm{ml}$ samples were placed in glass vials with a pinch of magnesium carbonate buffer and $10 \mathrm{ml}$ methanol, the vials were swirled and then placed in a water bath at $70^{\circ} \mathrm{C}$ for $10 \mathrm{~min}$. Three $\mathrm{ml}$ of the methanol extract was then centrifuged for $7 \mathrm{~min}$ at $2300 \mathrm{rpm}(769 \times \mathrm{g})$ before the supernatant was decanted and light absorbance measured with a UV/visible spectrophotometer (Varian DMS 80) at 2 wave lengths, 650 and $665 \mathrm{~nm}$. The chl a content of each sample was then calculated using the equation of Hoffman \& Werner (1966). As all the sediment samples were the same size, the data are presented as chl a concentration $(\mu \mathrm{g})$ per $7 \mathrm{ml}$ sediment.

Sediment samples for organic carbon analysis were placed in an oven at $60^{\circ} \mathrm{C}$ until they reached a constant weight. They were then combusted at $480^{\circ} \mathrm{C}$ in a muffle furnace for $6 \mathrm{~h}$ and the loss on ignition (LOI) \% of organic carbon calculated.

Readily available nitrates were extracted from $10 \mathrm{~g}$ of sediment using $110 \mathrm{ml}, 2 \mathrm{M} \mathrm{NaCl}$ and shaken for $1 \mathrm{~h}$. Sediment samples and sample blanks were filtered (Whatman 1/185 mm filter papers) following shaking and prior to analysis. Analysis consisted of passing samples through a cadmium column where nitrate is reduced to nitrite and can then be measured colourimetrically as part of an automated procedure using a flow injection analyser (FIAstar 5010 analyser, Tecator). The procedures we used were based on the American Public Health Association (1995) standard methods for analysis of wastewater. Samples were put through the flow injection analyser in batches of 25 and standards of concentrations between 0.1 and $0.75 \mu \mathrm{g} \mathrm{l}^{-1}$ were checked at least twice per batch. Two duplicate samples and one blank were also analysed per batch. Duplicate samples were required to differ by less than $20 \%$ in nitrate concentration. 

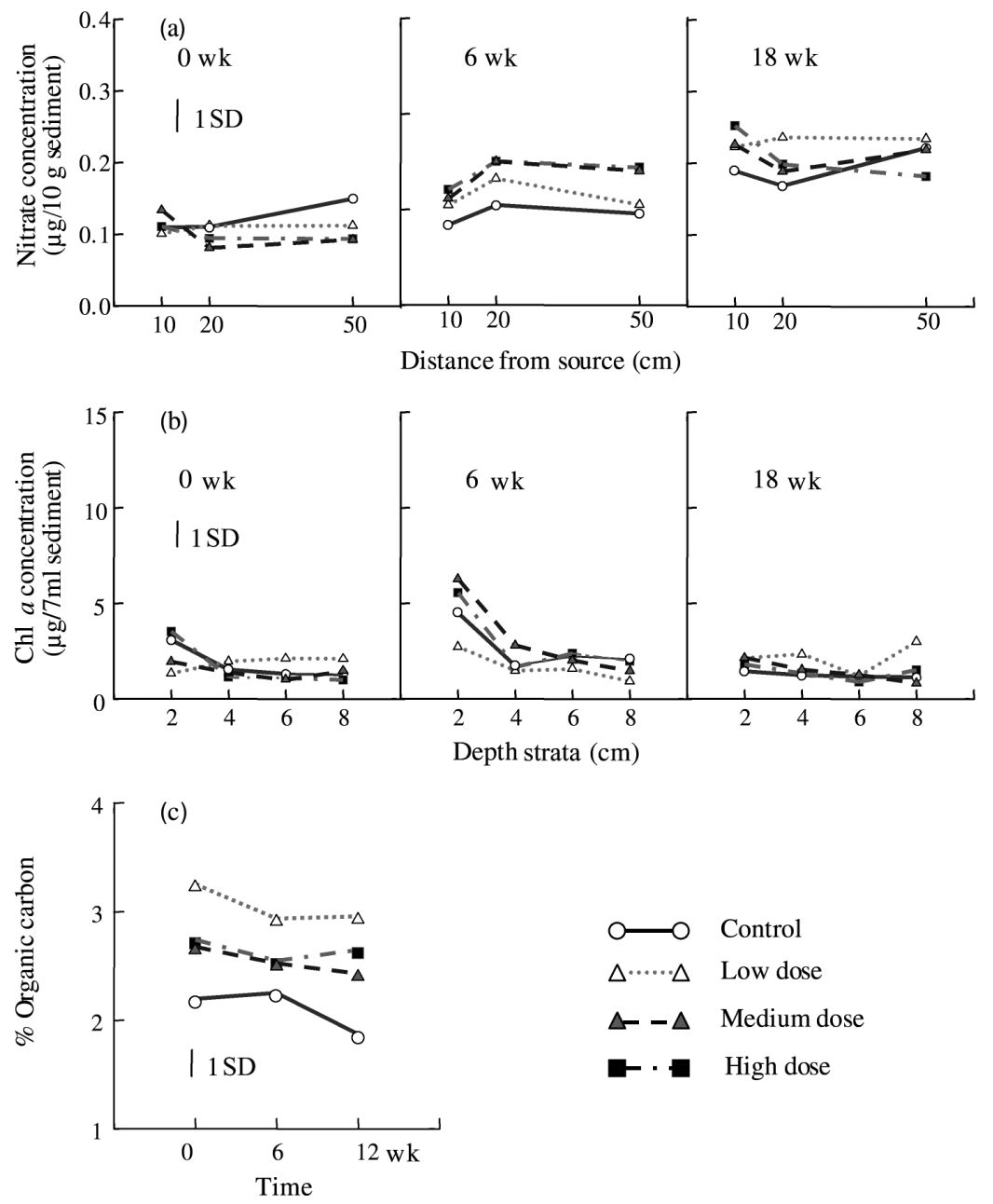

Fig. 1. Western Treatment Plant sediment chemistry data. (a) Concentrations of pore water nitrates for the 4 dose treatments at the 3 sampling occasions. Samples were taken at 3 distances from the dose point source, i.e. 10, 20 and $50 \mathrm{~cm}$. (b) Depth profiles of chl a concentrations for the 4 dose treatments at the 3 sampling occasions. (c) Organic carbon content in the top $2 \mathrm{~cm}$ of sediment at the 3 sampling occasions. Standard deviations are derived from the mean square error terms of the appropriate repeated measures ANOVA and represent a pooled estimate of variance. See 'Materials and methods' for further details sented, although there was only one instance where this was necessary. The population data is taken from taxa that constituted more than $1 \%$ of the assemblage.

Sediment chemistry data were regressed against faunal data to investigate any broader scale relationships between the sediment parameters and faunal measures at the WTP site. These analyses were only undertaken for the WTP data because there were few clear patterns in sediment chemistry at this site.

In the type of experimental design we have used, the test of the 'time by treatment' interaction is often the most biologically interesting. Consequently we have calculated power values for the test of this interaction. Stipulating biologically important effect sizes is still very difficult in the power analysis of ecological data (Fairweather 1991) and determining relevant effect sizes for an interaction can be even more daunting. We chose effect sizes that were consistent with changes considered to demonstrate an impact in a range of studies looking at the effects of sewage effluent on soft-sediment assemblages (Morris 2002). We considered a change of $50 \%$ in the medium dose plots and $100 \%$ in the high dose plots in comparison to the control plots over the course of the experiment to be biologically important. We predicted no change for the low dose plots. For the measures of ecological diversity, we stipulated an effect size of $25 \%$ change in the medium dose plots and 50\% change in the high dose plots from the control values over the course of the experiment. The 'Pi-face' add-in of Microsoft Excel was used for the power calculations.

Derived assemblage-level measures of ecological diversity were calculated by the PRIMER package using $\log _{\mathrm{e}}$ where appropriate.

Power to detect significant effects was generally low for the interactions of interest in these experiments. As a consequence of this, we have restricted graphical presentation of results to where we observed a significant effect of the interactions of interest $(p \leq 0.05)$ or, to where power values indicated that we could be at least $75 \%$ confident that we had detected a non-significant result for these interactions. As we are not interested in changes with time per se but only in how patterns of change might differ between control and experimental treatments, we have not presented graphs of measures that showed changes with time only. Standard deviations presented on all figures are derived from the

appropriate error term in the repeated measures
(H-F) epsilon value, and where transforming gre improved this value, the $\log _{10}(x+1)$ values are pre-
Statistical analysis. Repeated measures ANOVA was used to analyse a range of population and assemblagewithin dose and depth (5 levels, fixed). Where there were significant interactions, no attempts were made to analyse the main effects at each level of the other factor. Instead we have examined the data to draw conclusions about differences in the patterns of change a minimum keep the overall number of statistical tests to change rather than the absolute change. The assumption of sphericity was checked using the Huyn Feldt 
ANOVA. This is usually the Time $\times$ Plot (dose) mean square, as this is the error term for the time by dose interaction which is of particular interest in this study. The error bars represent a pooled estimate of variance. We used this measure of error because it more closely represented the variance against which hypotheses were tested and, as a consequence, was a more relevant measure than standard error bars (Quinn \& Keough 2002).

\section{RESULTS}

\section{Western Treatment Plant}

A total of 42 taxa were collected during the course of this experiment, although $99 \%$ of the fauna was made up of only 10 taxa. Oligochaete and polychaete worms, corophiid amphipods and bivalve molluscs numerically dominated the assemblage. Total abundance ranged from 64370 to 200960 ind. $\mathrm{m}^{2}$.

\section{Sediment chemistry}

There were no effects of the dose treatments on porewater nitrate concentrations at the WTP site although there was an increase in available nitrates with time (Fig. 1a, Table 1a). There was no indication that the nutrient addition was increasing pore-water nitrates close to the dose source. Chl a concentration also increased over time, with highest values being recorded at the $6 \mathrm{wk}$ sampling occasion in the top $2 \mathrm{~cm}$ of sediment (Fig. 1b, Table 1b.). While chl a concentrations appeared greatest in the high and medium dosed treatments after $6 \mathrm{wk}$, these differences were not significant (Fig. 1b, Table 1b). Organic carbon levels did not change over time or with dose treatment (Fig. 1c, Table 1c).

\section{Population measures}

Of the 10 most dominant taxa at the WTP site, the majority of animals were found in the top $2 \mathrm{~cm}$ of sediment at all times and there was little evidence to suggest that the nutrient additions were causing vertical migration within the sediment (Table 2, Fig. 2). Several taxa showed significant time by dose by depth effects, although the patterns of these interactions were not consistent. Patterns of change for the corophiid amphipod Gammaropsis sp. were similar in the dosed plots but differed from the control plots. Densities in the control plots decreased initially before increasing again, by a greater magnitude than the nutrient addition plots (Fig. 2b). These changes were mainly evident in the 0 to $2 \mathrm{~cm}$ depth fraction. Another amphipod, Limnoporeia kalduke, showed a different pattern of response. L. kalduke decreased in abundance in all

Table 1. Results from repeated measures ANOVA for sediment chemistry data at the Western Treatment Plant. (a) Nitrate levels ( $\mu \mathrm{g}$ per $10 \mathrm{~g}$ of sediment) recorded from 10, 20 and $50 \mathrm{~cm}$ distances from dosing pot. (b) Chl a levels ( $\mu \mathrm{g}$ per $20 \mathrm{ml}$ sediment at each depth strata for 3 sampling occasions). (c) \% organic carbon levels for the 3 sampling occasions. Samples were taken at each of the 3 sampling times $(0,6$ and $18 \mathrm{wk})$. p-values and the mean square (MS) error term are shown in the same column so that the full ANOVA table can be reconstructed if required. Values in bold indicate significant effects $(\alpha=0.05)$

\begin{tabular}{|c|c|c|c|c|c|c|}
\hline Source & df & $\mathrm{p} / \mathrm{MS}$ & Source & $\mathrm{df}$ & $\mathrm{p} / \mathrm{MS}$ & Power \% \\
\hline \multirow{2}{*}{\multicolumn{3}{|c|}{ (a) Between subjects }} & Within subjects & & & \multirow{8}{*}{76} \\
\hline & & & Time & 2 & $<0.001$ & \\
\hline Dose & 3 & 0.462 & Time $\times$ Dose & 6 & 0.281 & \\
\hline Plot (Dose) & 12 & 0.601 & Time $\times$ Plot(Dose) & 24 & 0.002 & \\
\hline Distance & 2 & 0.965 & Time $\times$ Distance & 4 & 0.086 & \\
\hline Dose $\times$ Distance & 6 & 0.461 & Time $\times$ Dose $\times$ Distance & 12 & 0.493 & \\
\hline Error (MS) & 22 & 0.002 & Error (MS) & 44 & 0.001 & \\
\hline Plot (Dose) MS & 12 & 0.002 & Time $\times$ Plot (Dose) MS & 24 & 0.003 & \\
\hline \multirow{2}{*}{\multicolumn{3}{|c|}{ (b) Between subjects }} & \multicolumn{3}{|l|}{ Within subjects } & \multirow{8}{*}{35} \\
\hline & & & Time & 2 & $<0.001$ & \\
\hline Dose & 3 & 0.981 & Time $\times$ Dose & 6 & 0.070 & \\
\hline Plot (Dose) & 12 & 0.051 & Time $\times$ Plot(Dose) & 24 & 0.138 & \\
\hline Depth & 3 & $<0.001$ & Time $\times$ Depth & 6 & $<0.001$ & \\
\hline Dose $\times$ Depth & 9 & 0.081 & Time $\times$ Dose $\times$ Depth & 18 & 0.796 & \\
\hline Error (MS) & 36 & 1.402 & Error (MS) & & 1.524 & \\
\hline Plot (Dose) MS & 12 & 0.161 & Time $\times$ Plot(Dose) MS & 96 & 2.134 & \\
\hline \multirow{2}{*}{\multicolumn{3}{|c|}{ (c) Between subjects }} & Within subjects & & & \multirow{4}{*}{99} \\
\hline & & & Time & 2 & 0.056 & \\
\hline Dose & 3 & 0.221 & Time $\times$ Dose & 6 & 0.693 & \\
\hline Error (MS) & 9 & 0.759 & Error (MS) & 18 & 0.058 & \\
\hline
\end{tabular}




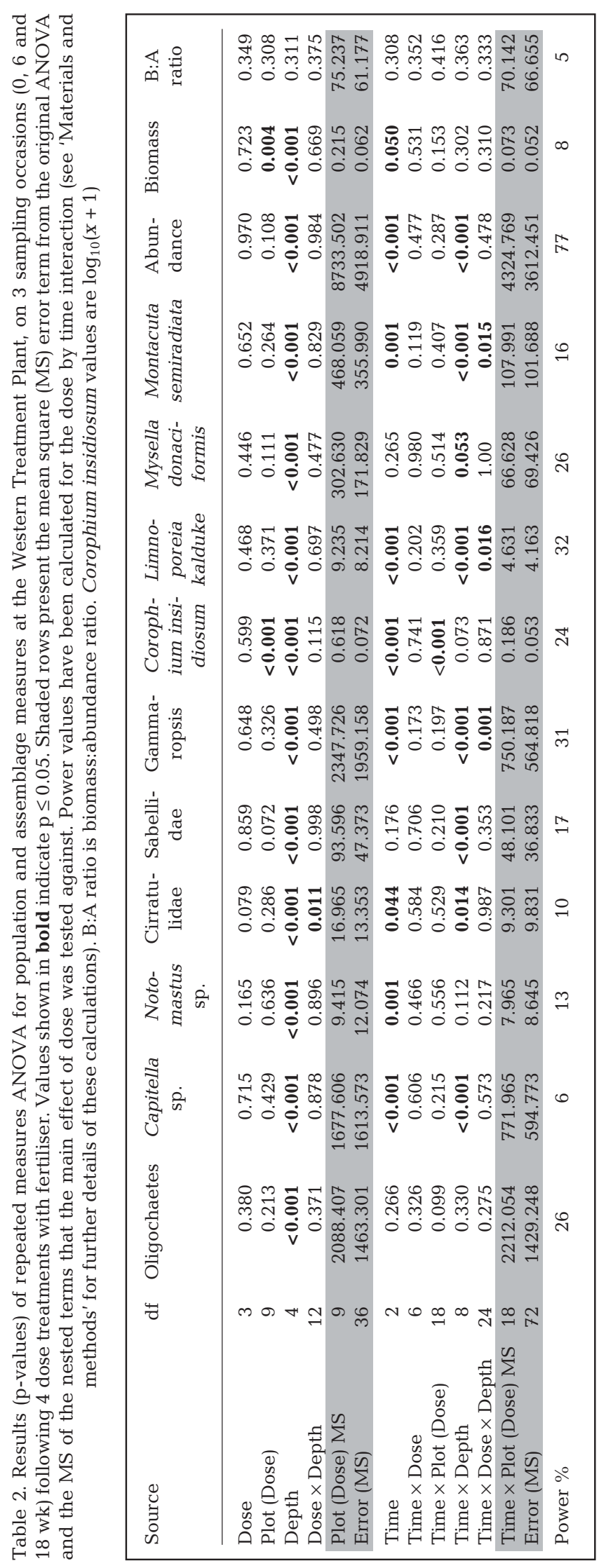

plots initially, except the high dose plots, before abundance again increased in all treatments. By the final sampling occasion the medium and high dose plots had densities of approximately 50 to $75 \%$ greater than the control or low dose plots (Fig. 2c). The pattern of response for the bivalve Montacuta semiradiata was dominated by an increase in abundance by approximately $100 \%$ in the high dose plots, compared to the other treatments, $18 \mathrm{wk}$ after initiation of dosing, and mean density was ordered by treatment for the medium dose, low dose and control plots (Fig. 2d).

Because consistently low values at the greater depths may have masked important effects in the top $2 \mathrm{~cm}$ depth fraction, we re-ran these analyses with data from the top $2 \mathrm{~cm}$ depth strata only. In this second set of analyses there was a significant time by dose interaction for the oligochaete worms $\left(F_{6,18} 2.686\right.$ $\mathrm{p}=0.048$ ) and a $200 \%$ increase in numbers in the high dose treatment at the $6 \mathrm{wk}$ sampling occasion in comparison to the initial sampling (Fig. 2a). By $18 \mathrm{wk}$, densities of these worms had dropped again in the high dose treatments but were elevated in the medium dose treatments. Conclusions regarding all the other taxa were not changed as a result of these supplementary analyses.

Of the remaining taxa, all showed either changes with time or time by depth interactions (Table 2), although again the pattern of these changes tended to differ for the various taxa. Regression analyses showed that some of these broad-scale changes in taxon abundance correlated with changes in sediment chemistry measures (Table 3 ) although $\mathrm{r}^{2}$ values tended to be low. For most of these taxa the direction of the relationship with sediment chemistry measures was positive.

The power to detect what we considered to be important biological changes in the treatment by time interaction term was low for all population measures at the WTP site, although the tests for changes in amphipod and oligochaete density with treatment and time were greater than for the other dominant taxa (Table 2).

\section{Total abundance, biomass and diversity measures}

Total abundance increased over the course of the experiment (Fig. 3a), although there was apparently no effect of nutrient addition on this measure, and power to detect our stipulated effect size of the treatment by time interaction was high (Table 2). The power to detect differences was very low for both total biomass and the biomass:abundance (B:A) ratio, and 
the high variability of the data may reflect the fact that we didn't make any adjustments for shell weights in molluscs. Previous work at the WTP site found the B:A ratio to provide a sensitive measure of change without adjusting for shell weights (Morris \& Keough 2002).

There were no effects of nutrient additions on the diversity measures (Table 4), yet although the diversity $\left(H^{\prime}\right)$ appeared lower in the control plots at the beginning of the experiment and remained lower throughout (Fig. 3), this difference was not significant (Table 3). Total number of taxa increased over the course of the experiment (Table 3). The power to detect treatment by time interactions tended to be high for the model we used, but only measures of abundance, diversity and eveness $(J)$ met the specified criteria of $75 \%$.

\section{Sand Island}

A total of 32 taxa were recorded from this site during the course of the experiment, although again, 99\% of the fauna was comprised of only 10 taxa. The fauna was numerically dominated by oligochaete and polychaete worms and bivalve and gastropod molluscs. Amphipod taxa found at the Western Treatment Plant site (corophiids, Limnoporeia kalduke) were present but were far less abundant at the Sand Island site. Total abundance ranged from 7379 to 44117 ind. $\mathrm{m}^{-2}$ during the course of the experiment.

\section{Sediment chemistry}

At Sand Island pore-water nitrate concentrations also increased with time, and were highest in all treatments $18 \mathrm{wk}$ after dosing was initiated (Table 5, Fig. 4a). Twelve weeks after the dosing began, nitrate concentrations were greatest in the high dose treatments close to the fertiliser source, suggesting that the addition of fertiliser was increasing sediment nitrate levels to at least $10 \mathrm{~cm}$ from the dose pot. At $18 \mathrm{wk}$, the medium dose plots showed elevated levels of nitrates (a) Oligochaetes

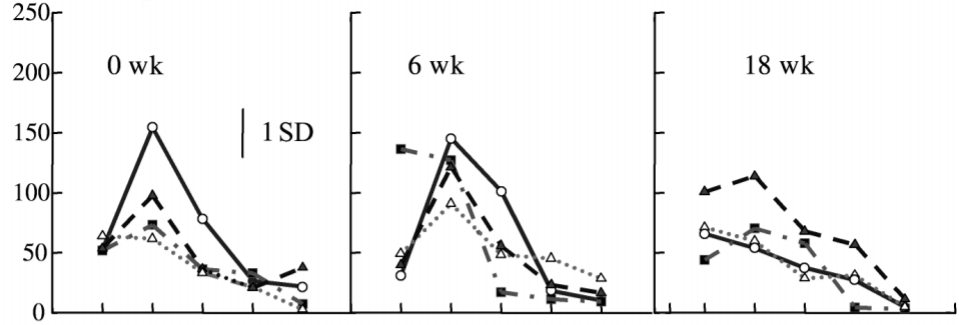

(b) Gammaropsis sp.

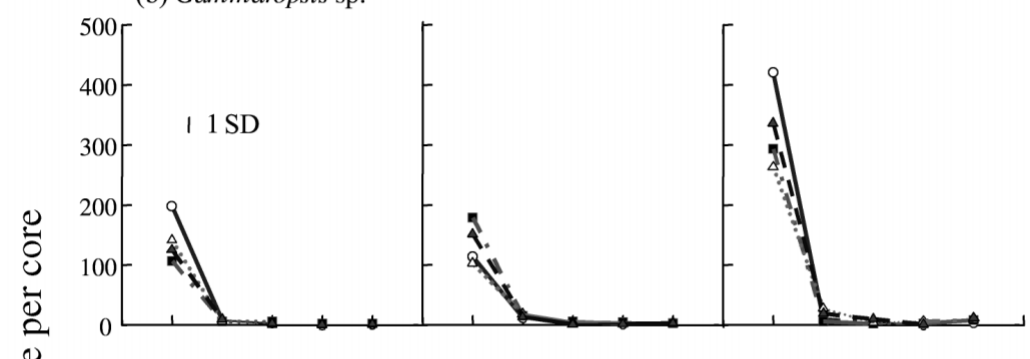

(c) Limnoporeia kalduke

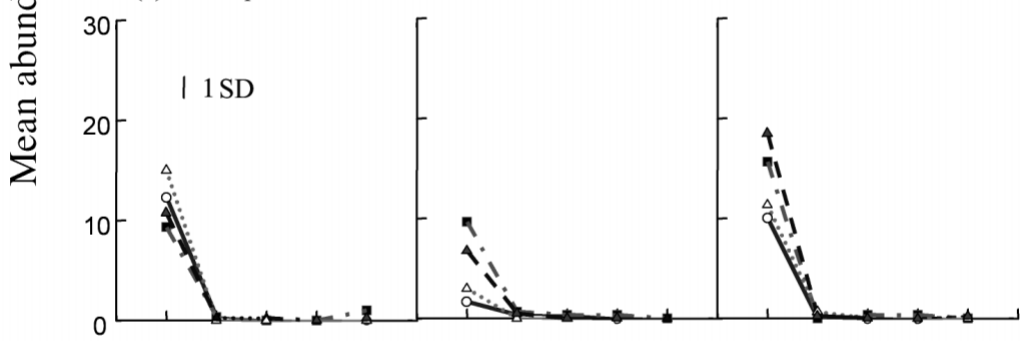

(d) Montacuta seminadiata

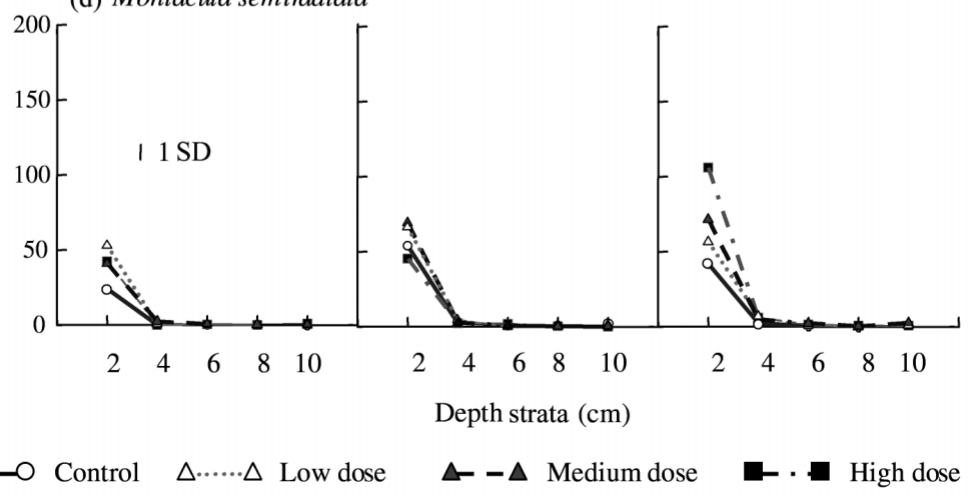

Fig. 2. Western Treatment Plant population level data. Depth profiles of (a) oligochaetes, (b) Gammaropsis sp. (c) Limnoporeia kalduke and (d) Montacuta semiradiata sampled at 0, 6 and 18 wk after initiation of dose treatments. Standard deviations are derived from the Time $\times$ Plot (dose) error term from the appropriate repeated measures ANOVA and represent a pooled estimate of variance. See 'Materials and methods' for further details

at a distance of $10 \mathrm{~cm}$ (Fig. 4a). As with the WTP site, chl a concentrations were greatest in the top $2 \mathrm{~cm}$ of sediment and at the initial sampling occasion that is, before dosing had begun, greater levels of chl a were 
recorded from the high dose plots than the other plots (Fig. 4b). This pattern had disappeared by $12 \mathrm{wk}$ and at $18 \mathrm{wk}$ chl a levels were approximately $66 \%$ lower in the high dose plots than they were when the experiment began. There was relatively little change in chl a concentrations throughout the course of the experiment for any of the other treatments. There was some evidence that organic carbon levels changed with time at this site, but no effect of nutrient addition was observed in organic carbon levels (Table 5, Fig. 4c).

\section{Population measures}

As with the WTP site, the majority of animals were found in the top $2 \mathrm{~cm}$ of sediment and there was little evidence to suggest that animals were migrating vertically as a result of the nutrient additions (Table 6). Several taxa, however, did differ in the pattern of abundance through time in response to the different treatments. The oligochaete worms had increased in abundance across all depths in the low dose plots by

(a) Total abundance

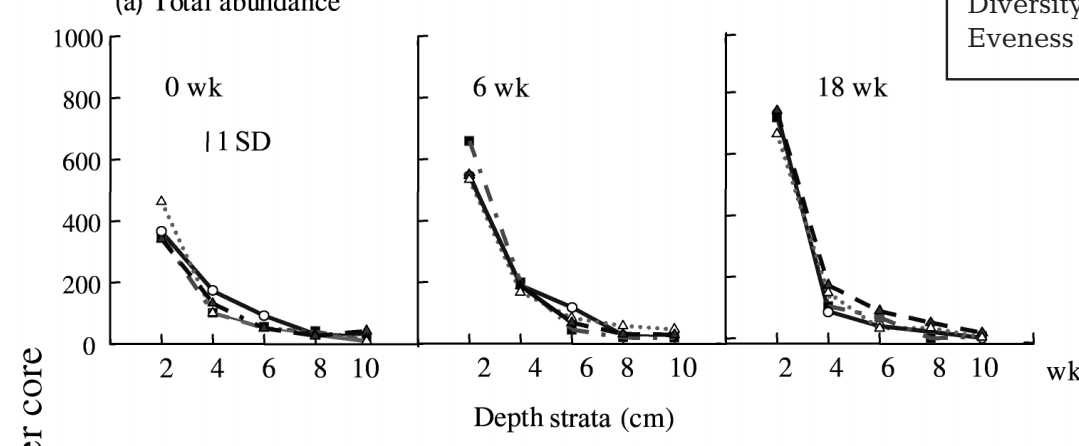

(b) Diversity $\left(H^{\prime} \log _{\mathrm{e}}\right)$

疍

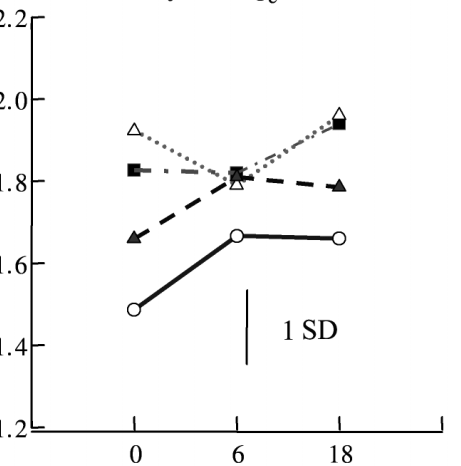

(c) Eveness $(J)$

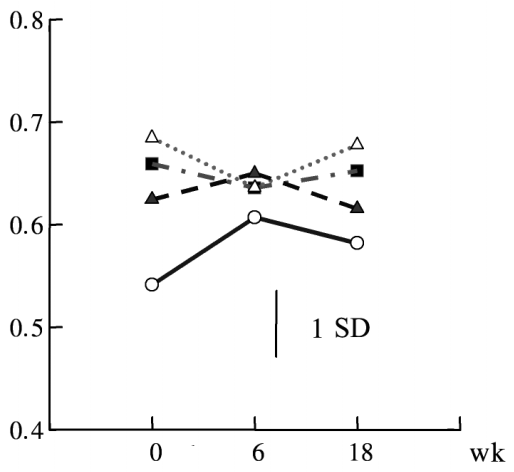

Time after initiation of dose treatments

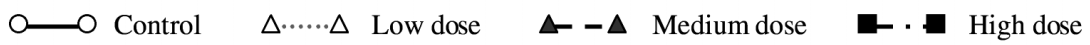

Fig. 3. Western Treatment Plant abundance and diversity data. (a) Depth profiles of mean abundance per core at 0,6 and $18 \mathrm{wk}$ after initiation of dose treatments. Mean values of (b) diversity $\left(H^{\prime}\right)$ and (c) eveness $(J) 0,6$ and 18 wk after initiation of dose treatments. Standard deviations are derived from the Time $\times$ Plot (dose) or the within subjects error terms from the appropriate repeated measures ANOVA and represent a pooled estimate of variance. See 'Materials and methods' for further details of these error bars
Table 3. Results from regressions of sediment chemistry measures on faunal data at the Western Treatment Plant site. Values shown in bold indicate $p<0.05$ and the direction of the regression relationships is also given where $\mathrm{p} \leq 0.05$ (Nitrates $=$ pore water nitrates; $\mathrm{OC}=$ organic carbon). $\mathrm{B}: \mathrm{A}$ is the biomass:abundance ratio

\begin{tabular}{|lccc|}
\hline Measure & $\begin{array}{c}\mathrm{NO}_{3} \\
\mathrm{r}^{2}\end{array}$ & $\begin{array}{c}\mathrm{Chl} \mathrm{a} \\
\mathrm{r}^{2}\end{array}$ & $\begin{array}{c}\mathrm{OC} \\
\mathrm{r}^{2}\end{array}$ \\
\hline Oligochaetes & 0 & 0 & 1 \\
Capitella sp. & 1 & 9 & 0 \\
Notomastus sp. & $\mathbf{1 7 +}$ & 4 & 10 \\
Cirratulidae & $\mathbf{1 1 +}$ & 2 & $\mathbf{1 4 +}$ \\
Sabellidae & 4 & 1 & $\mathbf{2 1 +}$ \\
Gammaropsis sp. & $\mathbf{5 0 +}$ & $\mathbf{1 0 -}$ & $\mathbf{1 3 -}$ \\
Corophium insidiosum & 1 & 3 & $\mathbf{3 6 +}$ \\
(log $\left.{ }_{10}+1\right)$ & & & \\
Limnoporeia kalduke & $\mathbf{1 7 +}$ & $\mathbf{1 2 -}$ & 1 \\
Mysella donaciformis & 3 & 2 & $\mathbf{1 7 +}$ \\
Montacuta semiradiata & 7 & 0 & $\mathbf{1 6 +}$ \\
Total abundance & $\mathbf{2 4 +}$ & 0 & 1 \\
Total biomass & 4 & 0 & 4 \\
Total B:A & 0 & 1 & 5 \\
No. taxa & $\mathbf{1 4 +}$ & 0 & 7 \\
Richness $(d)$ & $\mathbf{1 1 +}$ & 0 & 6 \\
Diversity $\left(H^{\prime}\right)$ & 2 & 2 & $\mathbf{3 6 +}$ \\
Eveness $(J)$ & 0 & 2 & $\mathbf{3 3 +}$ \\
& & & \\
\hline
\end{tabular}

the 12 wk sampling occasion, but by 18 wk abundance was $700 \%$ greater in the high dose plots in the top $2 \mathrm{~cm}$ compared to the medium and control plots at this sampling occasion (Fig. 5a). The bivalve Mysella donaciformis increased in abundance by approximately $33 \%$ in the control plots throughout the time of the experiment, while the pattern of change through time was similar in all dosed plots (Fig. 5c). By the final sampling occasion, densities in control plots ranged between approximately 75 and $600 \%$ greater than the dosed plots. The tipulids showed a $50 \%$ decrease in the control plots over the course of the experiment, while numbers in the high and low dose plots followed a different trajectory and increased by approximately $100 \%$ (Fig. 5e).

Several taxa (the syllid and terebellid polychaetes and the bivalve Montacuta semiradiata) showed a general increase in abundance over the course of the experiment, although both $M$. semiradiata and the Syllidae had a peak of abundance after 12 wk. The gastropod Salinator fragilis decreased in abundance 
Table 4. Results of repeated measures ANOVA (p-values) for diversity measures at the Western Treatment Plant at 3 sampling times $(0,6$ and $18 \mathrm{wk})$ following the addition of fertiliser. Values shown in bold indicate $\mathrm{p} \leq 0.05$. Rows highlighted present the mean square error term allowing reconstruction of the full ANOVA table if required. Power values have been calculated for the Dose $\times$ Time interaction (see 'Materials and methods' for further information)

\begin{tabular}{|lccccc|}
\hline Source & df & $\begin{array}{c}\text { No. } \\
\text { taxa }\end{array}$ & $\begin{array}{c}\text { Richness } \\
(\mathrm{d})\end{array}$ & $\begin{array}{c}\text { Diversity } \\
\left(H^{\prime}\right)\end{array}$ & $\begin{array}{c}\text { Eveness } \\
(J)\end{array}$ \\
\hline Dose & 3 & 0.473 & 0.350 & 0.084 & 0.113 \\
Error (MS) & 9 & 7.188 & 0.124 & 0.050 & 0.005 \\
Time & 2 & $\mathbf{0 . 0 1 1}$ & 0.086 & 0.333 & 0.977 \\
Time $\times$ Dose & 6 & 0.892 & 0.952 & 0.511 & 0.734 \\
Error $(\mathrm{MS})$ & 18 & 4.198 & 0.079 & 0.035 & 0.004 \\
Power\% & & 66 & 72 & 84 & 92 \\
\hline
\end{tabular}

throughout the experimental period, while numbers of another gastropod (Potamididae) remained fairly consistent (Fig. 5d). The supplementary analysis of the top 2 $\mathrm{cm}$ fraction provided no extra information at this site.

The power to detect impacts of nutrient additions through time was again low for most of the dominant taxa at this site. Only the gastropod family Potamididae met the stated criteria of $75 \%$ (Tables $6 \& 7$ ).

\section{Total abundance, biomass and diversity measures}

The depth distribution of total numbers of animals was affected by the treatments through time, with more animals in the low dose and control treatments penetrating to the 2 to $4 \mathrm{~cm}$ depth fraction. By $18 \mathrm{wk}$, densities of total number of animals were almost $100 \%$ greater in the high dose plots compared to the control plots, although the low dose nutrient additions also had approximately $50 \%$ greater densities than either the control or medium dose plots (Table 6, Fig. 6a). There was no effect of nutrient additions on total biomass during the experimental period but B:A ratios indicate that there was some evidence that the distribution with depth of different sized animals changed over the course of the experiment (Table 6).

The diversity measures in general also showed significant effects of nutrient additions through time (Table 7, Fig. 6b-d). Patterns of change for the total number of taxa were similar in the high and low dose plots and by the final sampling occasion were between 33 and $45 \%$ greater than the control and medium dose plots. Similarly, diversity increased in the high and low dose plots while the control and medium dose plots showed a pattern of initial increase and then decreased again at the 18 wk sampling occasion. Diversity was approxi-

Table 5. Results from repeated measures ANOVA for sediment chemistry data at Sand Island. (a) Nitrate levels ( $\mu \mathrm{g}$ per $10 \mathrm{~g}$ of sediment) recorded from 10, 20 and $50 \mathrm{~cm}$ distances from dosing pot. (b) Chl a levels ( $\mu \mathrm{g}$ per $20 \mathrm{ml}$ sediment at each depth strata for 3 sampling occasions). (c) \% organic carbon levels for the 3 sampling occasions. Samples were taken at each of the 3 sampling times $(0,12$ and 18 wk). p-values and the mean square (MS) error term are shown in the same column. Values in bold indicate significant effects when $\mathrm{p} \leq 0.05$

\begin{tabular}{|c|c|c|c|c|c|c|}
\hline Source & $\mathrm{df}$ & $\mathrm{p} / \mathrm{MS}$ & Source & $\mathrm{df}$ & $\mathrm{p} / \mathrm{MS}$ & Power \% \\
\hline \multirow{2}{*}{\multicolumn{2}{|c|}{ (a) Between subjects }} & & Within subjects & & & \multirow{8}{*}{92} \\
\hline & & & Time & 2 & $<0.001$ & \\
\hline Dose & 3 & 0.860 & Time $\times$ Dose & 24 & 0.105 & \\
\hline Plot (Dose) & 12 & 0.404 & Time $\times$ Plot(Dose) & 6 & 0.224 & \\
\hline Distance & 2 & 0.159 & Time $\times$ Distance & 4 & 0.050 & \\
\hline Dose $\times$ Distance & 6 & 0.016 & Time $\times$ Dose $\times$ Dist & 12 & 0.156 & \\
\hline Error (MS) & 24 & 0.004 & Error (MS) & 48 & 0.004 & \\
\hline Plot (Dose) MS & 12 & 0.004 & Time $\times$ Plot(Dose) MS & 24 & 0.005 & \\
\hline \multirow{2}{*}{\multicolumn{2}{|c|}{ (b) Between subjects }} & & Within subjects & & & \multirow{8}{*}{44} \\
\hline & & & Time & 2 & $<0.001$ & \\
\hline Dose & 3 & 0.509 & Time $\times$ Dose & 6 & 0.175 & \\
\hline Plot (Dose) & 12 & 0.129 & Time $\times$ Plot (Dose) & 24 & 0.108 & \\
\hline Depth & 4 & $<0.001$ & Time $\times$ Depth & 8 & 0.047 & \\
\hline Dose $\times$ Depth & 12 & 0.673 & Time $\times$ Dose $\times$ Depth & 24 & 0.029 & \\
\hline Error (MS) & 47 & 1.016 & Error (MS) & 94 & 0.652 & \\
\hline Plot(dose) MS & 12 & 1.609 & Plot (Dose) MS & 24 & 0.942 & \\
\hline \multirow{2}{*}{\multicolumn{2}{|c|}{ (c) Between subjects }} & & Within subjects & & & \multirow{4}{*}{100} \\
\hline & & & Time & 2 & 0.057 & \\
\hline Dose & 6 & 0.198 & Time $\times$ Dose & 6 & 0.503 & \\
\hline Error (MS) & 12 & 0.052 & Error (MS) & 24 & 0.026 & \\
\hline
\end{tabular}


mately $30 \%$ greater in high dose plots by the final sampling occasion than in the control plots. The pattern for the measure of eveness $(J)$ showed similar trajectories for the control and low dose plots, which were more or less opposite to that recorded in the medium and high dose plots. Power to detect the stipulated effect size was high for all measures of diversity.

\section{DISCUSSION}

Predictions about the effects of nutrients on benthic assemblages include changes in species composition. At the Sand Island site there was evidence to suggest
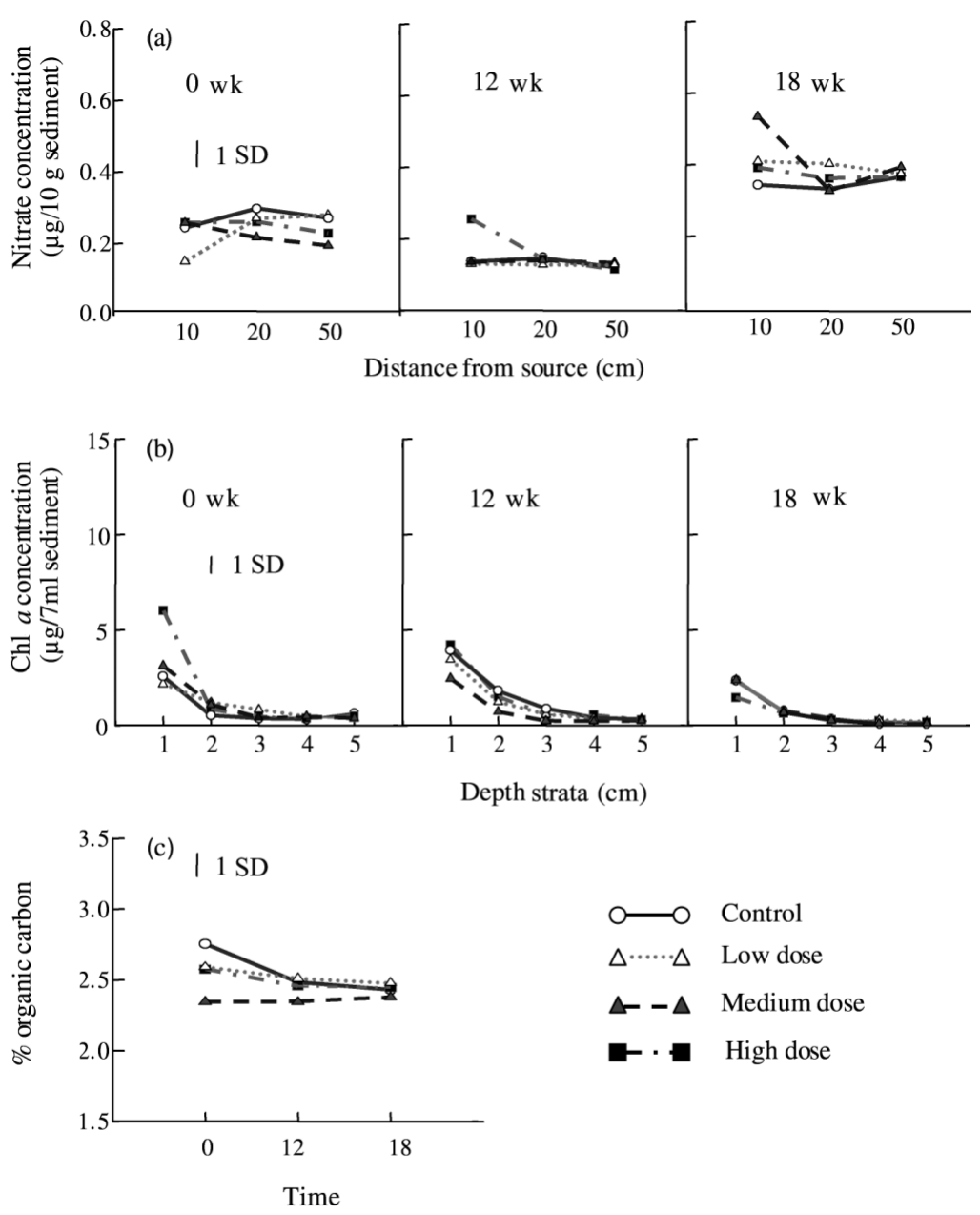

Fig. 4. Sand Island sediment chemistry data. (a) Concentrations of pore water nitrates for the 4 dose treatments at the 3 sampling occasions. Samples were taken at 3 distances from the dose point source, i.e. 10, 20 and $50 \mathrm{~cm}$. (b) Depth profiles of chl a concentrations for the 4 dose treatments at the 3 sampling occasions. (c) Organic carbon content in the top $2 \mathrm{~cm}$ of sediment at the 3 sampling occasions. Standard deviations are derived from the mean square error term or the within subjects error term from the appropriate repeated measures ANOVA and represent a pooled estimate of variance that the number of taxa and the numerical distribution of those taxa within the assemblage (diversity measures) were affected by nutrient additions. Increases in benthic microalgal standing stock may be expected to increase the dominance and abundance of grazers and deposit feeders (Posey et al. 1999), but an increase in food availability may also enable a variety of taxa with different food requirements and competitive abilities to survive. While a mechanism of competitive exclusion, resulting from competition for food, is not generally shown in soft sediment environments (e.g. Peterson 1977), a meta-analysis by Worm et al. (2002) found increases in diversity following the addition of nutrients in low productivity environments in a range of aquatic communities.

Other experimental fertilisation studies on benthic fauna have produced variable responses in univariate measures of assemblage structure. Hall et al. (2000) reported increases in measures of diversity in a fertilised temperate reef assemblage, and Dauer et al. (1982) found evidence that species number was greater in fertilised plots not open to predators. Conversely, Schratzberger \& Warwick (1998) reported decreases in a range of univariate measures of a meiofaunal assemblage following fertilisation. Wiltse et al. (1984) also provide some evidence to suggest that the number of macrofaunal species was reduced in fertilised plots. The general consensus from these studies is that in areas of low ambient nutrient availability, measures of diversity and species richness are likely to increase with fertilisation, whilst in areas with high background nutrient loadings there is likely to be a decrease. The present study provides some additional weight to these conclusions as increases in a range of univariate measures of diversity were recorded at the Sand Island site but not at the WTP site. The latter can be considered an extremely productive environment, although the productivity is not reflected in chlorophyll biomass but in faunal densities.

Changes in assemblage structure may also be reflected in numerical measures of abundance, and at Sand Island there was an increase in faunal abundance in the fertilised plots, again suggesting that nutrient additions were increasing food supply and so enabling the system to support greater densities of benthic invertebrates. No changes in biomass or average individual size (B:A ratios) directly attributable to dose treatments were recorded at either site, but this might be because these measures tend to be dominated by larger taxa and so any changes in the biomass of smaller taxa will be undetectable. 
We predicted that any changes in the abundance measures and assemblage structure would be the result of changes in deposit feeding or grazing populations. At Sand Island we found substantial increases in the numerically dominant oligochaetes and the tipulid insect larvae in both high and low dose treatments in comparison to controls. The sub-surface deposit feeding oligochaetes showed the most marked changes with nutrient additions, increasing initially in the low dose treatments across the entire depth strata and then showing increases in abundance in the high dose treatments. Sarda (1996) found that oligochaetes eventually dominated the infauna of fertilised creek systems, and Nilsson et al. (1991) also found that oligochaetes increased in abundance in fertilised mesocosms. Oligochaete worms have frequently been reported as responding positively to the occurrence of organic pollutants such as sewage effluents (Pearson \& Rosenberg 1978). This experiment provides evidence that they will also respond to increases in dissolved inorganic nutrients alone, suggesting that the nutrient component of organic effluents is an important factor driving changes in the distributions of these taxa.

Although fertilisation is predicted to increase productivity, this may not translate to increases in algal biomass. Instead, grazers and deposit feeders might increase in abundance, or per capita consumption of algae might increase resulting in a net reduction in algal biomass (Biggs \& Lowe 1994). The reduction in chl a that we observed in the high dose plots, coupled with large increases of deposit feeding oligochaetes, implies that nutrient availability is an important regulating factor for oligochaete populations at the Sand Island site.

There were several notable exceptions to the positive response of deposit feeding populations to nutrient additions. The 2 gastropod species recorded at the Sand Island site either showed no response at all, with treatment or time (Potamididae), or showed a general reduction over time (Salinator fragilis). (a) Oligochaetes

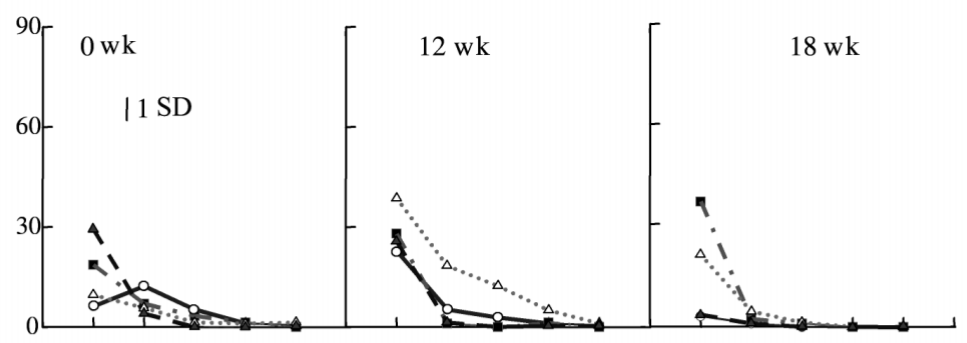

(b) Capitella sp.

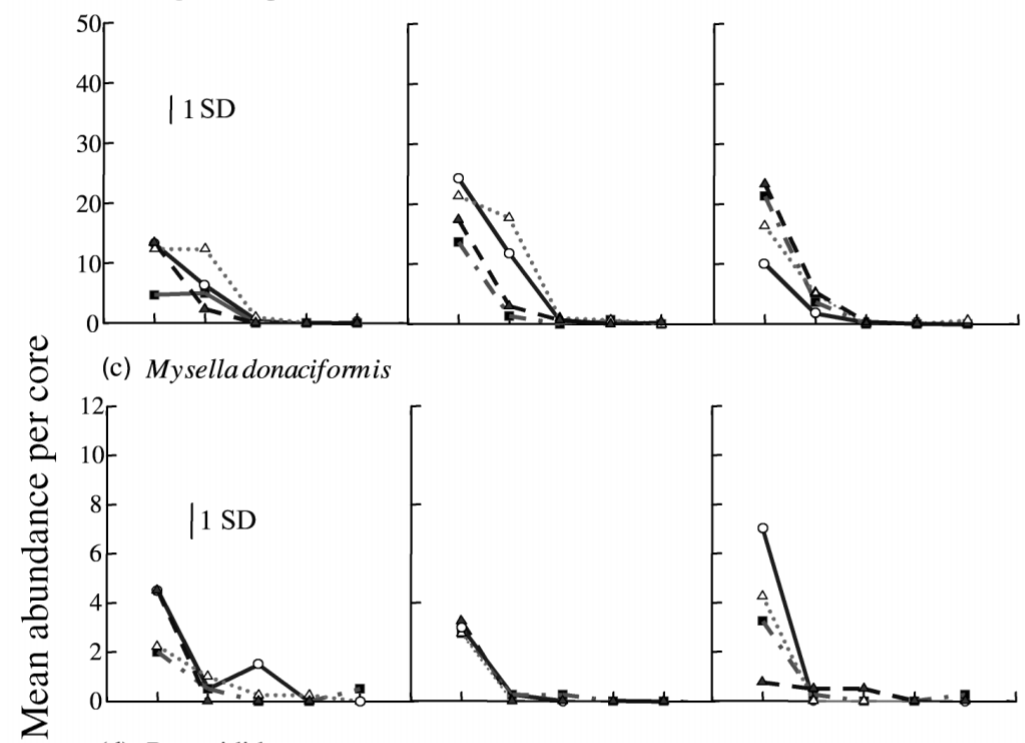

(d) Potamididae

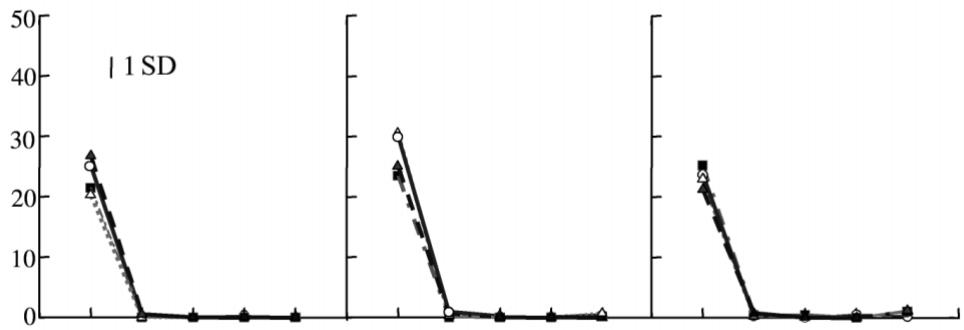

(e) Tipulidae

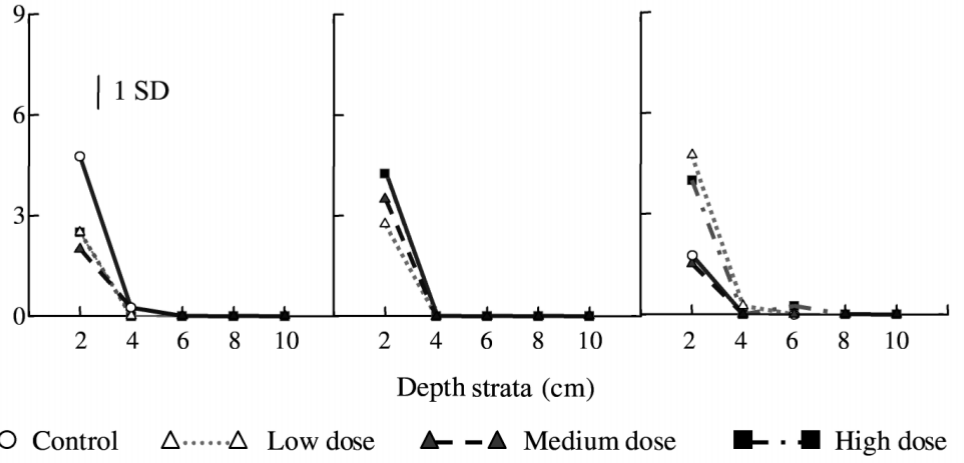

Fig. 5. Sand Island population level data. Depth profiles of (a) Oligochaetes, (b) Capitella sp., (c) Mysella donaciformis, (d) Potamididae, and (e) Tipulidae sampled at 0,12 and $18 \mathrm{wk}$ after initiation of dose treatments. Standard deviations are derived from the Time $\times$ Plot (dose) mean square error term from the appropriate repeated measures ANOVA and represent a pooled estimate of variance 


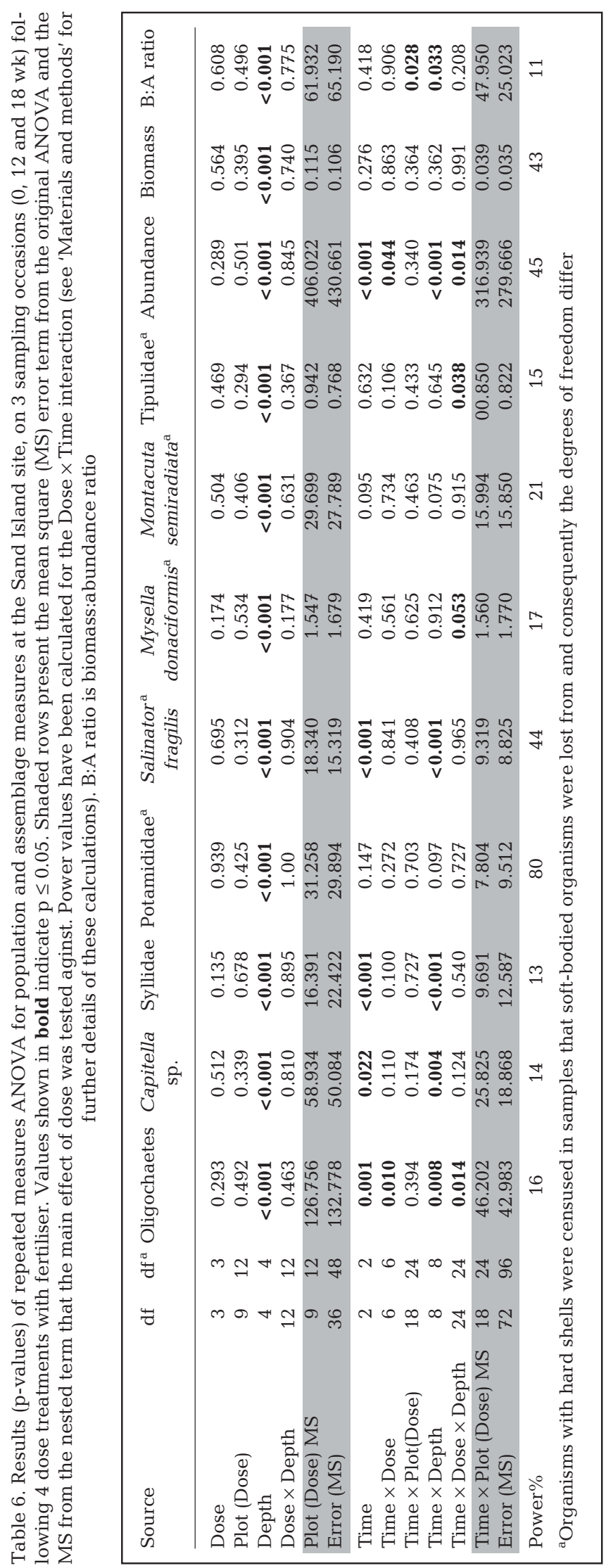

Gastropods have been shown to respond to nutrient additions in fresh water (Biggs \& Lowe 1994), and a lack of response in this experiment is surprising.

Where we did see effects of nutrient additions at Sand Island there was no indication that a doseresponse pattern was evident. While the changes in the high dose plots were fairly consistent, there was also evidence that both the low and medium dose additions were having an effect on the faunal assemblage, often the low dose treatments showing a pattern of change more similar to the high dose treatments. While the reason for this variability in response is not clear, it does suggest that even relatively low levels of nutrient addition are enough to stimulate changes in benthic invertebrate assemblages at this site. This is despite the fact that we are trying to detect changes over and above a level of natural variation that is happening on a scale far larger than our experimental plots, and that may have masked the smallerscale changes. The larger-scale changes may also have been acting in opposite directions to the nutrient additions, so that effects of dosing were evident as a lack of change in comparison to controls, rather than increases or decreases. These types of effects potentially explain why we did not see consistent effects of the nutrient additions through time.

At the WTP site, total faunal abundance increased with time, and the majority of the deposit feeding populations showed changes in abundance during the experimental period but there were few apparent effects of nutrient additions. As with the Sand Island site, the oligochaetes showed a strong positive response to the high dose treatments in the top $2 \mathrm{~cm}$.

Responses to dose additions were less marked at the WTP compared to Sand Island in terms of the magnitude of responses, as well as the number of measured endpoints that responded to nutrient additions. The reason for this may relate to differences in physical, chemical or biological processes at the 2 sites. It is noteworthy that nitrate levels were actually higher at the Sand Island site by the end of the experiment in comparison to the WTP. This is surprising because nutrient loads to the bay increase dramatically every year over the period of these experiments due to operational changes to the treatment processes at the WTP (Harris et al. 1996). Large increases in effluent flow occur at the Murtcaim Drain, (situated $4 \mathrm{~km}$ southwest of the experimental site) and nitrogen removal efficiency in Lake Borrie, which discharges into Port Phillip Bay via the Lake Borrie drain, also deteriorates over this time period (T. Scott pers. comm.). As a consequence we would have predicted that sediment nitrate levels would be higher at the WTP site. Interestingly many of the population- and assemblage-level endpoints measured showed changes over the experimental period, 
which implies that large-scale changes in nutrients can be rapidly translated into invertebrate biomass at this site. The soft sediment environment at the WTP is able to support much greater densities of infaunal invertebrates in comparison to the Sand Island site, and these benthic assemblages are generally thought to be important in the processing of nutrients in the bay (Bird 1994).

While these processes are not fully understood, local rates of denitrification are thought to depend, in part, on the structure of the sediments, and may be strongly enhanced by burrowing organisms that increase bioirrigation rates and create strong $\mathrm{O}_{2}$ gradients (Murray \& Parslow 1999, but see Berelson et al. 1998 for a contrasting view). This would mean that between-site differences in nitrogen flux are likely, and the same dose (or absolute change in N) applied at both sites could potentially have a very different fate, possibly resulting in a smaller increase in available nitrogen at the WTP in comparison to Sand Island.

The enriched environment of the WTP not only supports greater densities of infaunal organisms than Sand Island, but the area also plays host to very high numbers of wading birds (Steele 1996) and may be an important feeding area for fish. These experiments provide evidence that the Sand Island invertebrate fauna are regulated by bottom-up controls such as pore-water nutrient availability, and it is possible that the limiting nutrients are readily available phosphates rather than nitrates in this sandier sediment (Nicholson et al. 1996). At the WTP, however, moderate additions of nutrients may have no visible impact on the infauna, due to high rates of uptake at all trophic levels and competitive interactions acting in the opposite direction to any effects of the nutrient additions (Thrush 1991).

While it is not clear whether the observed differences between sites relate to the specific fate of the available nutrients or to differences in biologically mitigating effects such as increased predation, identifying such differences is a valuable first step, with important management implications. At Sand Island, changing the nutrient status of the area is liable to result in rapid changes in deposit-feeding populations as well as assemblage structure. At the WTP the same absolute change in $\mathrm{N}$ may not have any immediate impact on the invertebrate fauna. (a) Total abundance

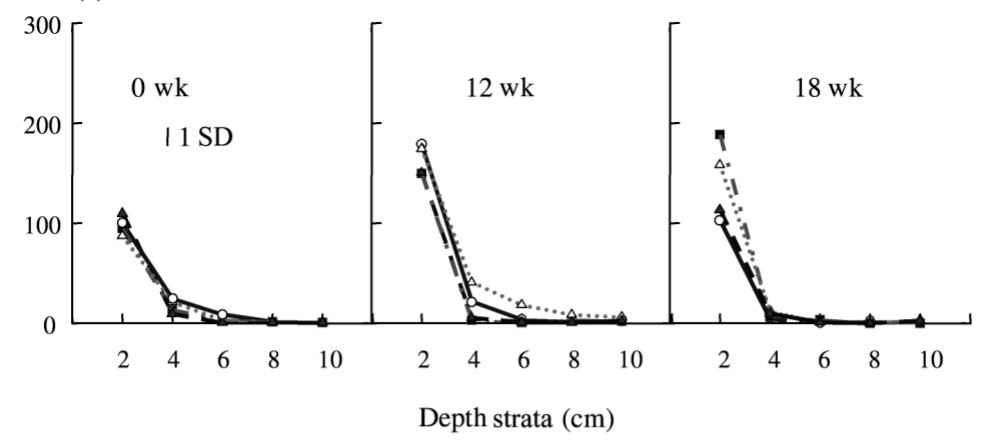

(b) Total number of taxa

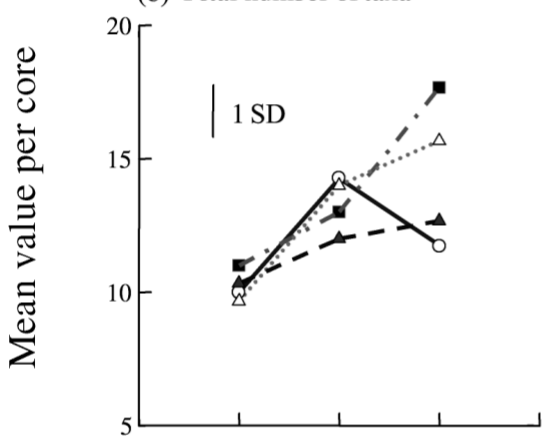

(d) Diversity $\left(H^{\prime} \log _{\mathrm{e}}\right)$

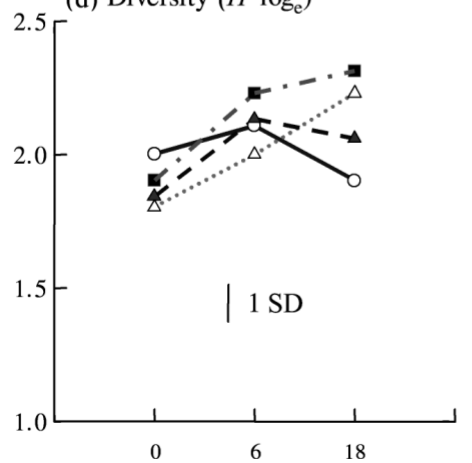

(c) Species richness (Margalefs $d$ )

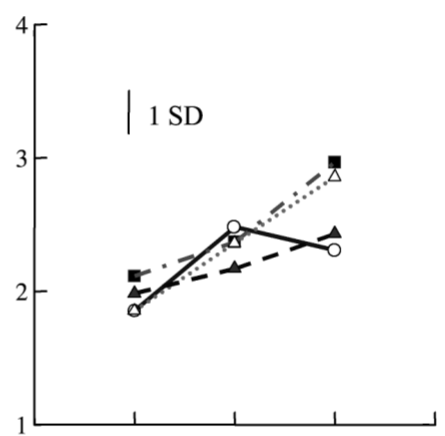

(e) Eveness $(J)$

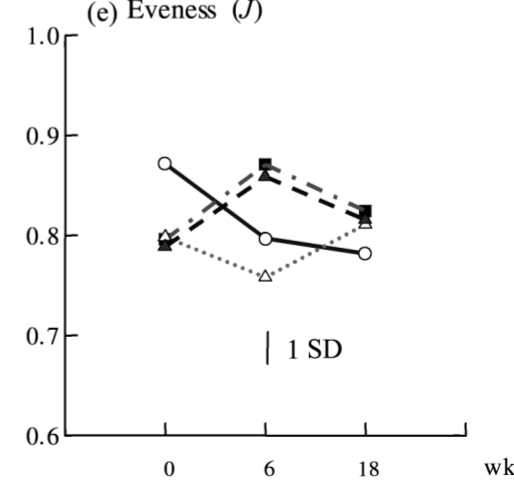

Time after initiation of dose treatments

○ C Control $\quad \Delta \cdots \cdot \Delta$ Low dose $\quad \boldsymbol{\sim}-\boldsymbol{- \Delta}$ Medium dose

- High dose

Fig. 6. Sand Island assemblage level data. (a) Depth profiles of total abundance per core at 0,12 and $18 \mathrm{wk}$ after initiation of dose treatments. Mean values of total number of (b) taxa, (c) species richness (Margalefs $d$ ), (d) diversity $\left(H^{\prime}\right)$ and (e) eveness $(J) 0,12$ and 18 wk after initiation of dose treatments. Standard deviations are derived from the Time $\times$ Plot (dose) or the within subjects error terms from the appropriate repeated measures ANOVA and represent a pooled estimate of variance 
Table 7. Results of repeated measures ANOVA (p-values) for taxa that were only found in the top $2 \mathrm{~cm}$ of sediment and diversity measures at the Sand Island site at 3 sampling times $(0,12$ and $18 \mathrm{wk})$ following the addition of fertiliser. Values shown in bold indicate $\mathrm{p} \leq 0.05$. Shaded rows present the mean square error term allowing reconstruction of the full ANOVA table if required. Power values have been calculated for the Dose $\times$ Time interaction (see 'Materials and methods' for further information)

\begin{tabular}{|c|c|c|c|c|c|c|c|c|}
\hline Source & df & $\mathrm{df}^{\mathrm{a}}$ & Nereidae $^{a}$ & Terebellidae $^{a}$ & No. taxa & Richness $(d)$ & Diversity $\left(H^{\prime}\right)$ & Eveness $(J)$ \\
\hline Dose & 3 & 3 & 0.875 & 0.470 & 0.044 & 0.126 & 0.432 & 0.558 \\
\hline Error (MS) & 9 & 9 & 183.944 & 55.185 & 2.420 & 0.069 & 0.045 & 0.004 \\
\hline Time & 2 & 1 & 0.121 & 0.054 & $<0.001$ & $<0.001$ & $<0.001$ & 0.683 \\
\hline Time $\times$ Dose & 6 & 3 & 0.708 & 0.166 & 0.056 & 0.270 & 0.023 & 0.007 \\
\hline Error (MS) & 18 & 9 & 47.630 & 21.704 & 3.75 & 0.098 & 0.019 & 0.001 \\
\hline Power\% & & & 73 & 10 & 94 & 99 & 100 & 100 \\
\hline
\end{tabular}

Acknowledgements. We thank Melbourne Water and the Department of Natural Resources and Environment for access to field sites and the Department of Geography, University of Melbourne, for loan of equipment and assistance with some of the chemical analysis. We would also like to thank Sara Long, Belinda Cant and Tom Tomlin for field and laboratory assistance. Emma Johnston, Terry Scott and Andy Longmore and 2 anonymous referees read and improved earlier drafts of this manuscript. A Melbourne University Research Scholarship supported L.M. during this study.

\section{LITERATURE CITED}

American Public Health Association (1995) Standard methods for the examination of water and wastewater. APHAAWWA-WEF. American Public Health Association and Water Environment Federation, Washington, DC

Ball D, O'Callaghan P (1997) Queenscliff Harbour environmental values study. A report for Parks Victoria by the Marine and Freshwater Resources Institute, Queenscliff

Berelson WM, Heggie D, Longmore A, Kilgore T, Nicholson G, Skyring G (1998) Benthic nutrient recycling in Port Phillip Bay, Australia. Estuar Coast Shelf Sci 46:917-934

Biggs BJF, Lowe RL (1994) Responses of 2 trophic levels to patch enrichment along a New Zealand stream continuum. NZ J Mar Freshw Res 28:119-134

Biggs BJF, Francoeur SN, Huryn AD, Young R, Arbuckle CJ, Townsend CR (2000) Trophic cascades in streams: effects of nutrient enrichment on autotrophic and consumer benthic communities under 2 different fish predation regimes. Can J Fish Aquat Sci 57:1380-1394

Bird FL (1994) The effects of bioturbation in Port Phillip Bay. Technical report No. 14, Port Phillip Bay Environmental Study. CSIRO, Canberra

Breitburg DL, Sanders JG, Gilmour CC, Hatfield CA, Osman RW, Riedel GF, Seitzinger SP, Sellner G (1999) Variabilty in responses to nutrients and trace elements and transmission of stressor effects through an estuarine food web. Limnol Oceanogr 44:837-863

Bulthius DA, Axelrad DM, Mickelson MJ (1992) Growth of the seagrass Heterozostera tasmanica limited by nitrogen in Port Phillip Bay, Australia. Mar Ecol Prog Ser 89: 269-275

Cahoon LB, Nearhoof JE, Tilton CL (1999) Sediment grain size effect on benthic microalgal biomass in shallow aquatic ecosystems. Estuaries 22:735-741

Ceccherelli G, Cinelli F (1997) Short term effects of nutrient enrichment of the sediment and interactions between the seagrass Cymodocea nodosa and the introduced green alga Caulerpa taxifolia in a Mediterranean bay. J Exp Mar Biol Ecol 217:165-177

Dauer DM, Ewing MR, Tourtellotte GH, Harlan WT, Sourbeer JW, Barker HR (1982) Predation resource limitation and the structure of benthic infaunal communities of the lower Chesapeake Bay. Int Rev Gesamt Hydrobiol 67:477-489

Downing JA, Osenberg CW, Sarnell O (1999) Meta-analysis of marine nutrient-enrichment experiments: variation in the magnitude of nutrient limitation. Ecology 80:1157-1167

Erftemeijer PA, Stapel J, Smekens MJE, Drossaert WME (1994) The limited effect of in situ phosphorous and nitrogen additions to seagrass beds on carbonate and terrigenous sediments in south Sulawesi, Indonesia. J Exp Mar Biol Ecol 182:123-140

Fairweather P (1991) Statistical power and design requirements for environmental monitoring. Aust J Mar Freshw Res 42:555-567

Fenchel TM, Riedl RJ (1970) The sulfide system: a new biotic community underneath the oxidized layer of marine sand bottoms. Mar Biol 7:255-268

Fleury BG, Coll JC, Tentori E (2000) Effect of nutrient enrichment on the complementary (secondary) metabolite composition of the soft coral Sarcophyton ehrenbergi (Cnidaria: Octocorallia: Alcyonaceae) of the Great Barrier Reef. Mar Biol 136:63-68

Hall SJ, Gray SA, Hammett ZL (2000) Biodiversity-productivity relations: an experimental evaluation of mechanisms. Oecologia 122:545-555

Harris G, Batley G, Fox D, Hall D and 7 others (1996) Port Phillip Bay Environmental Study, Final Report. CSIRO, Canberra

Heggie DT, Skyring GW, Orchado J, Longmore AR, Nicholson GJ, Berelson WM (1999) Denitrification and denitrifying efficiencies in sediments of Port Phillip Bay: direct determinations of biogenic $\mathrm{N}_{2}$ and $\mathrm{N}$-metabolite fluxes with implications for water quality. Mar Freshw Res 50: 589-596

Hill AS, Hawkins SJ (1990) An investigation of methods for sampling microbial films on rocky shores. J Mar Biol Assoc UK 70:77-88

Hoffman P, Werner D (1966) Spectrophotometric chlorophyll determination having special regard to various types of equipment. Jena Rev 7:300-303

Houser JN, Carpenter SR, Cole JJ (2000) Food web structure and nutrient enrichment: effects on sediment phosphorous retention in whole-lake experiments. Can J Fish Aquat Sci 57:1524-1533

Hunter MD, Price PW (1992) Playing chutes and ladders: het- 
erogeneity and the relative roles of bottom-up and topdown forces in natural communities. Ecology 73:724-732 Kenworthy WJ, Fonesca MS (1992) The use of fertilizer to enhance growth of transplanted seagrasses Zostera marina (L) and Halodule wrightii (Aschers.). J Exp Mar Biol Ecol 163:141-161

Llanso RJ (1991) Tolerance of low dissolved oxygen and hydrogen sulfide by the polychaete Streblospio benedicti (Webster). J Exp Mar Biol Ecol 153:165-178

McGlathery KJ (1995) Nutrient and grazing influences on a subtropical seagrass community. Mar Ecol Prog Ser 122: 239-252

McQueen DJ, Johannes MRS, Post JR, Stewart TJ, Lean DRS (1989) Bottom-up and top-down impacts on freshwater pelagic community structure. Ecol Monogr 59:289-309

Menge BA (1992) Community regulation: under what conditions are bottom-up factors important on rocky shores? Ecology 73:755-765

Morris EC (2002) The effects of a treated sewage effluent on an intertidal soft-sediment assemblage: pattern and process. PhD thesis, University of Melbourne

Morris L, Keough MJ (2002) Organic pollution and its effects: a short-term transplant experiment to assess the ability of biological endpoints to detect change in a soft sediment environment. Mar Ecol Prog Ser 225:109-121

Murray AG, Parslow JS (1999) Modelling of nutrient impacts in Port Phillip Bay - a semi-enclosed marine Australian ecosystem. Mar Freshw Res 50:597-611

Nicholson GJ, Longmore AR, Cowdell RA (1996) Nutrient status of the sediments of Port Phillip Bay. Technical Report No. 26, Port Phillip Bay Environmental Study, CSIRO, Canberra

Nilsson P, Jonsson B, Lindstrom Swanberg I, Sundback K (1991) Response of a marine shallow-water sediment system to an increased load of inorganic nutrients. Mar Ecol Prog Ser 71:275-290

Pearson TH, Rosenberg R (1978) Macrobenthic succession in relation to organic enrichment and pollution of the marine environment. Oceanogr Mar Biol Annu Rev 16:229-311

Pearson TH, Rosenberg R (1987) Feast and famine: structuring factors in marine benthic communities. In: Gee JHR, Giller PS (eds) Organization of communities past and present. Blackwell Scientific Publications, Oxford, p 373-395

Peterson CH (1977) Competitive organisation of the softbottom macrobenthic communities of southern Californian lagoons. Mar Biol 43:343-359

Posey MH, Powell C, Cahoon L, Lindquist D (1995) Top down vs. bottom up control of benthic community composition on an intertidal tideflat. J Exp Mar Biol Ecol 185:19-31

Posey MH, Alphin TD, Cahoon L, Lindquist D, Becker M

Editorial responsibility: John Gray (Contributing Editor), Oslo, Norway
(1999) Interactive effects of nutrient additions and predation on infaunal communities. Estuaries 22:785-792

Quinn GP, Keough MJ (2002) Experimental design and data analysis for biologists. Cambridge University Press, Cambridge

Riebsell JF (1974) Paradox of enrichment in competitive systems. Ecology 55:183-187

Rosenberg R, Hellman B, Johansson B (1991) Hypoxic tolerance of marine benthic fauna. Mar Ecol Prog Ser 79: $127-131$

Sarda R, Valiela I, Foreman K (1996) Decadal shifts in a salt marsh macroinfaunal community in response to sustained long term experimental nutrient enrichment. J Exp Mar Biol Ecol 205:63-81

Schratzberger M, Warwick RM (1998) Effects of the intensity and frequency of organic enrichment on 2 estuarine nematode communities. Mar Ecol Prog Ser 164:83-94

Snelgrove PVR, Butman CA (1994) Animal-sediment relationships revisited: cause versus effect. Oceanogr Mar Biol Annu Rev 32:111-177

Steele WK (1996) Annotated bibliography of literature relating to the effects of changes to effluent flows and nutrient loads on the populations of waterbirds and their prey species: with particular reference to the Western Treatment Plant, Victoria. R Aus Ornithol Union Rep 112:1-93

Sundback K, Jonsson B, Nilsson P, Lindstom I (1990) Impact of accumulating drifting macroalgae on a shallow water sediment system: an experimental system. Mar Ecol Prog Ser 58:261-274

Taylor DL, Eggleston DB (2000) Effects of hypoxia on an estuarine predator-prey interaction: foraging behaviour and mutual interference in the blue crab Callinectes sapidus and the infaunal clam prey Mya arenaria. Mar Ecol Prog Ser 196:221-237

Thrush SF (1991) Spatial patterns in soft-bottom communities. Tree 6:75-79

Vetter EW (1996) Enrichment experiments and infaunal population cycles in a Southern Californian sand plain: response of the leptostracan Nebalia daytoni and other infauna. Mar Ecol Prog Ser 137:83-93

Wiltse WI, Foreman KH, Teal JM, Valiela I (1984) Effects of predators and food resources on the macrobenthos of salt marsh creeks. J Mar Res 42:923-942

Worm B, Reusch TBH, Lotze H K (2000) In situ nutrient enrichment: methods for marine benthic ecology. Int Rev Hydrobiol 85:359-375

Worm B, Lotze HK, Hillebrand H, Sommer U (2002) Consumer versus resource control of species diversity and ecosystem functioning. Nature 417:848-851

Submitted: January 15, 2002; Accepted: October 21, 2002 Proofs received from author(s): March 3, 2003 